\title{
ULTRASTRUCTURAL STUDIES ON THE UTEROVAGINAL SPERM-HOST GLANDS OF THE DOMESTIC HEN, GALLUS DOMESTICUS
}

\author{
M. D. TINGARI* AND P. E. LAKE \\ A.R.C. Poultry Research Centre, King's Buildings, \\ West Mains Road, Edinburgh EH9 $37 S$
}

(Received 28th Fuly 1972)

\begin{abstract}
Summary. Ultrastructural studies were made on the uterovaginal sperm-host glands from virgin and inseminated hens. Their fine structure differs only in the presence of spermatozoa in the glandular lumina. Ciliated and non-ciliated epithelial cells were present; the former occurred in the neck region of the tubular glands and merged with the general vaginal surface epithelium.

The true glandular epithelium was composed of non-ciliated cells which showed evidence of high metabolic and secretory activities. The secretion contained carbohydrate and lipid but apocrine secretion rich in glycogen was also observed occasionally. The significance of these secretions in relation to the survival of the stored spermatozoa is discussed. The non-ciliated cells contained many cytoplasmic filaments resembling tonofibrils. It is suggested that these confer contractility on the gland cells, so mobilizing the spermatozoa in response to unknown periodic stimuli associated with oviposition or ovulation.

The stored spermatozoa did not form an intimate association with the lining cells of the glands but the covering membranes of the heads of spermatozoa adhered to each other. It is suggested that this might be due to the absence of antiagglutinating factors in the sperm-host glands.
\end{abstract}

\section{INTRODUCTION}

Tubular glands are known to be present near the uterovaginal junction of the domestic hen (Giersberg, 1922) and are believed to act as storage sites for spermatozoa (Bobr, Lorenz \& Ogasawara, 1962, 1964; Fujii \& Tamura, 1963; Schindler, Ben-David, Hurwitz \& Kempenich, 1967; Takeda, 1967; Van Krey, Ogasawara \& Pangborn, 1967; Burke, Ogasawara \& Fuqua, 1972). Spermatozoa are stored in these glands following copulation or artificial insemination; they are discharged periodically into the oviduct and transported

* Present address: Department of Anatomy, Faculty of Veterinary Science, University of Khartoum, P.O. Box 32, Khartoum N., Sudan. 
to the infundibulum, where they may also reside temporarily and effect fertilization soon after ovulation. The glands are known under several names based upon their location and function, i.e. vaginal glands (Giersberg, 1922; Fujii, 1963), mucous glands (Richardson, 1935), sperm-host glands (Lorenz, Reynolds \& Howard, 1966; Lorenz, Reynolds \& Gilbert, 1967), sperm-glands (Van Krey et al., 1967), uterovaginal sperm-host glands (Gilbert, Reynolds \& Lorenz, 1968) and uterovaginal sperm-storage glands (Burke et al., 1972). The designation 'uterovaginal sperm-host glands' is used in this study, considering the location of these glands and their simple function of acting as a storage site for spermatozoa.

Accounts of the histology of the glands are given by Richardson (1935), Fujii (1963), Bobr, Lorenz \& Ogasawara (1964) and Van Krey et al. (1967); their histochemistry has been investigated by Fujii (1963) and Gilbert et al. (1968). Previous ultra-structural studies have been confined to seeking explanations for the method(s) by which spermatozoa may be released cyclically from the storage site; the cells lining the gland itself have received only little attention (Schindler et al., 1967; Van Krey et al., 1967; Burke et al., 1972). A detailed examination of the glands from virgin and inseminated hens was undertaken in the present study to obtain further information on their normal ultrastructure, the mode of storage of spermatozoa, and whether or not the presence of spermatozoa in the glands elicits any changes in the gland cell activity.

\section{MATERIALS AND METHODS}

Twelve hens were examined; three were virgins, and the remainder were inseminated with 0.05 to $0.1 \mathrm{ml}$ undiluted, pooled semen freshly collected by abdominal massage from cocks of proven fertility.

The hens were killed by an overdose of Nembutal (Abbott Laboratories Ltd); inseminated hens were killed at intervals of 1,2, 4 and 5 days after receiving semen. The body cavity was opened immediately, the oviduct posterior to the shell gland region was dissected out and a longitudinal incision was made to expose the lining surface of the uterovaginal junction. This part was transferred to a Petri dish and covered with ice-cold $5 \%$ glutaraldehyde in phosphate buffer. It was examined subsequently under a dissecting microscope to identify the area of glandular tissue, small pieces of which were then dissected out and transferred to fresh fixative for $1 \mathrm{hr}$. Fixation was carried out occasionally on an anaesthetized bird by perfusion through the heart, followed by immersion of the dissected glandular area of the oviduct.

The tissues were washed in buffer after fixation, osmicated for $1 \mathrm{hr}$ (Millonig, 1962), dehydrated in ethanol, cleared in propylene oxide and embedded in Araldite according to the schedule described by Maxwell \& Trejo (1970). Thick sections were cut with glass knives, stained with toluidine blue and examined with the light microscope. Thin sections from the desired regions were cut with a diamond knife, mounted on uncoated copper grids, stained with alcoholic uranyl acetate (Stempak \& Ward, 1964) and lead citrate (Reynolds, 1963) and examined with an AEI EM 6B or Philips EM 300 electron microscope. 


\section{RESULTS}

The uterovaginal sperm-host glands were tubular invaginations of the mucosa on the vaginal side of the uterovaginal junction. Most of the glands were simple tubules but branching is occasionally observed (see Lake (1967) and Burke et al. (1972) for overall structure of the gland). The epithelial lining was simple columnar with two cell types; ciliated and non-ciliated. The epithelium in the proximal part of the gland was formed exclusively of ciliated cells (P1. 1, Fig. 1) which merged at the surface with the general lining cells of the oviduct. Deeper in the neck of the gland, the ciliated cells alternated singly or in groups with the non-ciliated cells and eventually disappeared. Thus, the latter (PI. 2, Fig. 2) were the only cells lining the deepest regions of the gland and formed the true glandular epithelium.

The epithelium of the glands was bounded by a basal lamina which showed little or no folding. The external surface of this lamina was associated with scattered collagenous fibres and some fine filamentous material which was probably tropocollagen. No myoepithelial cells were present.

\section{The fine structure of the ciliated cell}

The ciliated cells were tall and irregularly wedge-shaped with a tapering basal part. The luminal border carried motile cilia which showed the characteristic structure composed of ' $9 \times 2+2$ ' microtubules, a ciliary shaft, a basal body and cross-striated rootlets (Pl. 1, Fig. 1). Slender microvilli, simple or branching, were interspersed between the cilia. The lateral plasma membranes showed little or no folding, and were closely apposed at the luminal tips to those of adjacent cells by junctional complexes (Pl. 1, Fig. 1).

The nucleus was centrally located, irregularly oval and showed few surface invaginations. In addition to a nucleolus, small clumps of chromatin were seen within the nucleoplasm and along the surface of the inner nuclear membrane. Smooth endoplasmic reticulum (SER) was confluent with the closely packed cisternae and vacuoles in the supranuclear region, which constituted the Golgi complex (PI. 1, Fig. 1); small membrane-bound dense granules were associated with its periphery. Oval or elongated mitochondria with the typical configuration were concentrated mainly around the ciliary rootlets and in the apical cytoplasm. Many cytoplasmic vacuoles containing electron-dense granules were seen in the same region of the cell as the mitochondria and appeared to be positioned for extrusion into the Iumen (Pl. 1, Fig. 1). Profiles of rough endoplasmic reticulum were scattered at random throughout the ciliated cells and abounded in the infranuclear cytoplasm. Some free ribosomes were also present in the cytoplasm.

Large vacuolar spaces occurred in both the luminal and basal areas of the cytoplasm which did not resemble the granule-containing vacuoles indicated above (Pl. 1, Fig. 1). The vacuoles probably represented lipid droplets which were leached out during processing.

The fine structure of the non-ciliated 'glandular' cells

The non-ciliated cell found mainly in the deeper region of the uterovaginal 
sperm-host glands was tall, slender and often pyramidal in shape. The luminal border was fringed with closely packed microvilli essentially of the same size and shape and giving the appearance of a striated border (Pl. 2, Fig. 2). Bleblike projections, indicating apocrine secretion, were found between the microvilli or lying free in the lumen (Pl. 2, Fig. 3). Projections may sometimes have undergone disintegration when free glycogen particles were seen in the lumen. Occasionally, a large mass of cytoplasm containing a variable quantity of glycogen was seen in the lumen (Pl. 2, Fig. 3) and was presumed to arise from projections of the secretory cells. A few micropinocytotic vesicles were seen occasionally interspersed between the microvilli. The lateral plasma membranes were not folded in the luminal half of the cell. They were attached apically to

\section{EXPLANATION OF PLATES}

\section{PLATE 1}

FIG. 1. Giliated cells found in the neck of the uterovaginal sperm-host glands of the hen, with typical motile cilia $(\mathbf{C})$ and interspersed microvilli. Junctional complexes $(J)$ are seen at the luminal tips of the lateral plasma membranes. A small Golgi complex (GC), electron-dense granules $(G)$, mitochondria (M), large vacuoles (V) and parts of nuclei (N) are demonstrated.

\section{PLATE 2}

FIg. 2. The apical part of typical non-ciliated cells found in the deeper region of a sperm-host gland of the hen, showing closely packed microvilli. Extensive junctional complexes $(\mathrm{J})$ are evident at the border of adjacent cells in the luminal part of the cells and desmosomes (D) occur more caudally. Glycogen particles and fine cytoplasmic filaments are scattered throughout the cytoplasm. Large electron-dense membrane-bound granules are also present (arrows).

Fig. 3. The Iuminal border of non-ciliated cells showing bleb-like projections (arrows). A large one (B) is detached forming part of an apocrine secretion. Note glycogen particles in the cytoplasm of the cells in bleb-like projections and also in a detached element of cytoplasm in the lumen (seen on the right of the picture).

\section{PLATE 3}

Fig. 4. The basal parts of non-ciliated cells of the sperm-host gland of the hen. The lateral plasma membranes in these parts possess numerous irregularly orientated membranous folds $(M)$. Note the absence of contractile elements in the subepithelial stroma which is essentially composed of collagenous fibres.

Frg. 5. Cytoplasmic vacuoles (V) and accumulations of glycogen particles in their vicinity are common features of the non-ciliated cells. Stacks of non-striated filaments (F) are seen in the cytoplasm.

Fro. 6. Cytoplasmic vacuole (arrow) in a non-ciliated cell showing an electron-lucent centre and a dense peripheral part.

\section{PLATE 4}

Fig. 7. Massive accumulation of glycogen particles closely associated with a cytoplasmic vacuole in a non-ciliated cell of the sperm-host gland of the hen.

FrG. 8. A non-ciliated cell showing a sizeable Golgi complex (GC), electron-dense granules associated with glycogen particles $(G)$, a number of oval or elongated mitochondria (M) and bundles of non-striated filaments $(F)$.

\section{PLATE 5}

FIG. 9. Spermatozoa stored in the lumen of the host gland of the hen. Note their orientation being parallel to that of the long axis of the gland and their heads pointing distally towards the blind end.

Fig. 10. Transverse section cutting most of the stored spermatozoa across the head regions. The enveloping plasma membranes appear to adhere to each other (arrows) and associate with the microvilli of the lining cells (double arrows). 


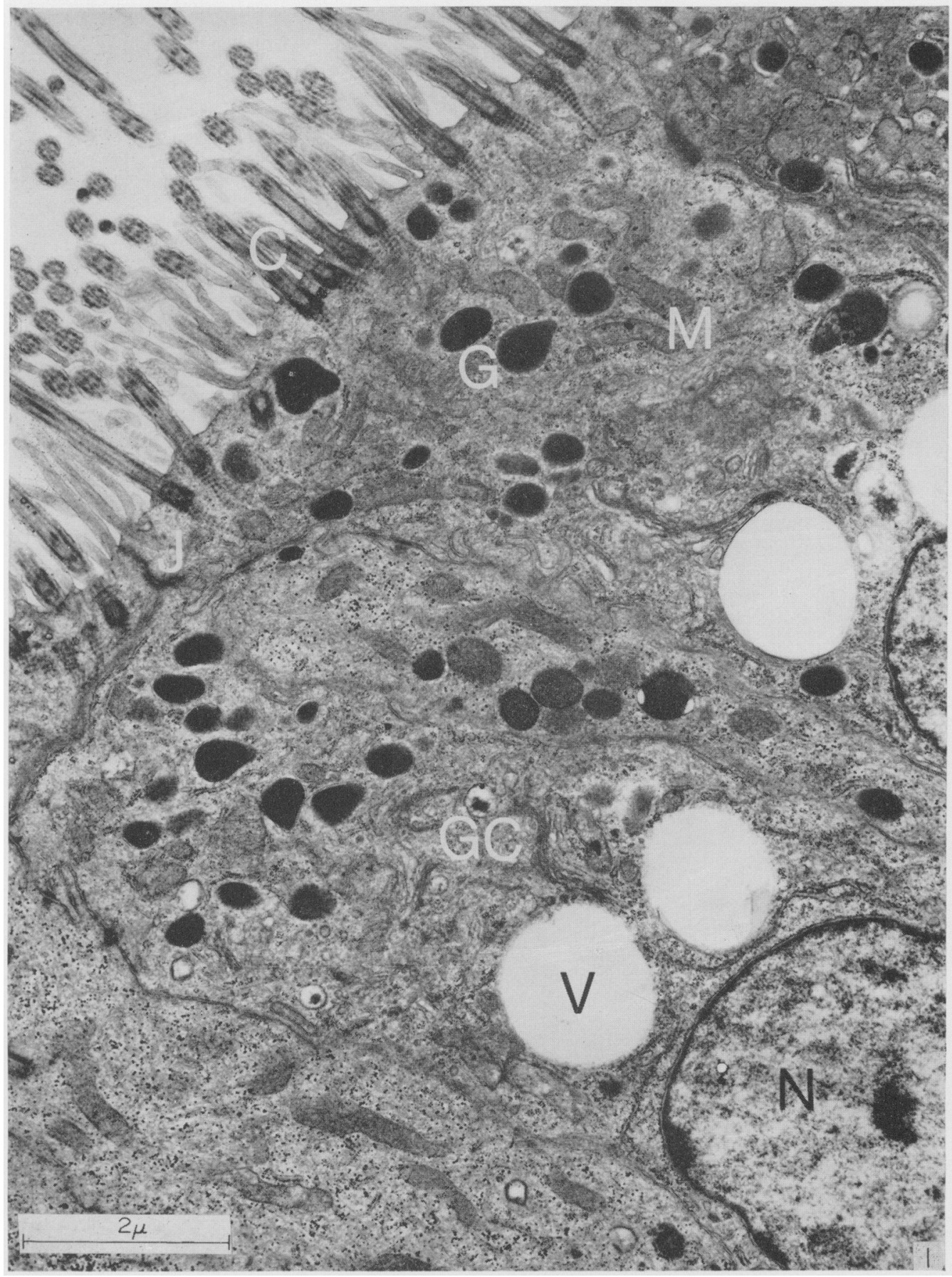




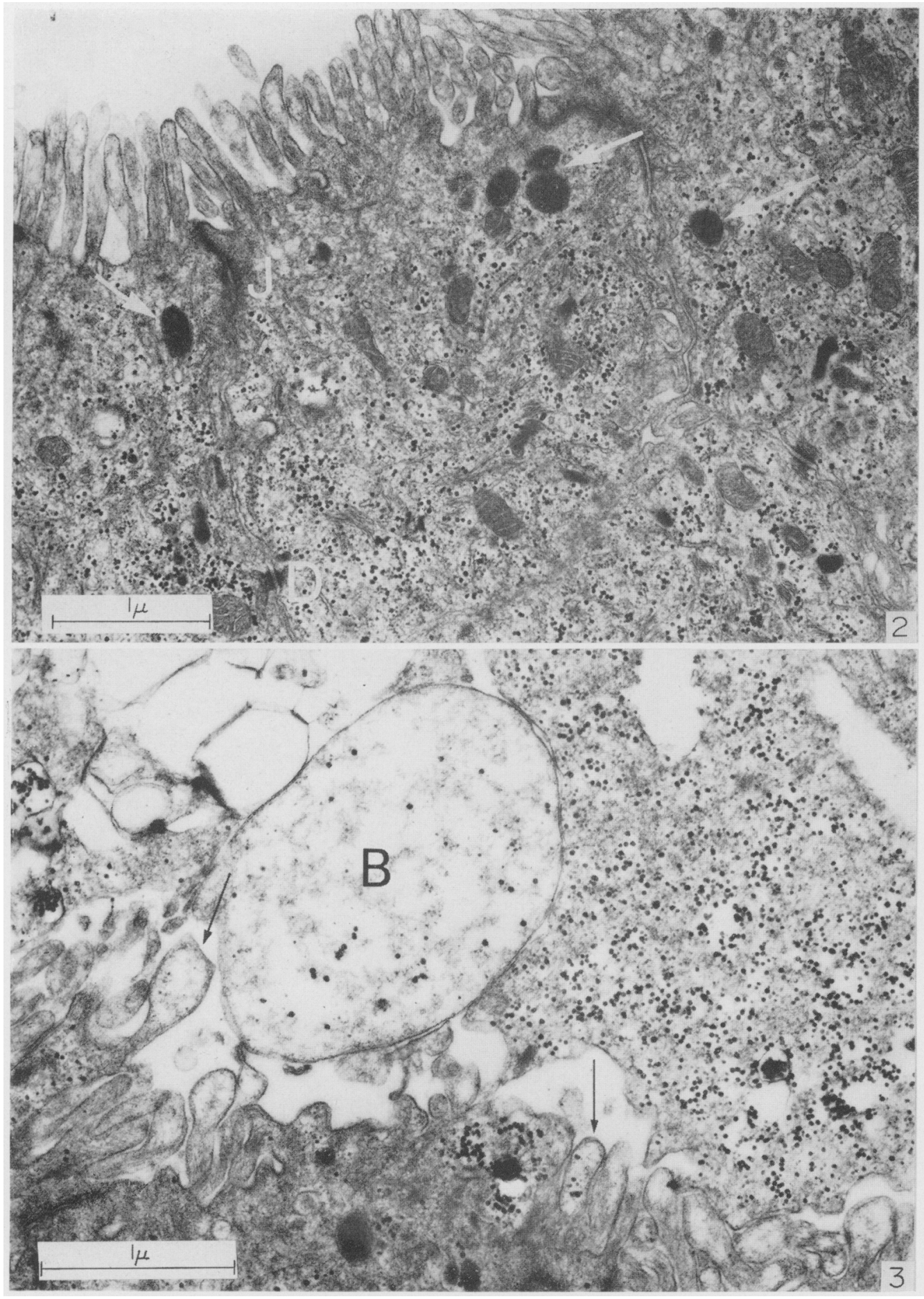




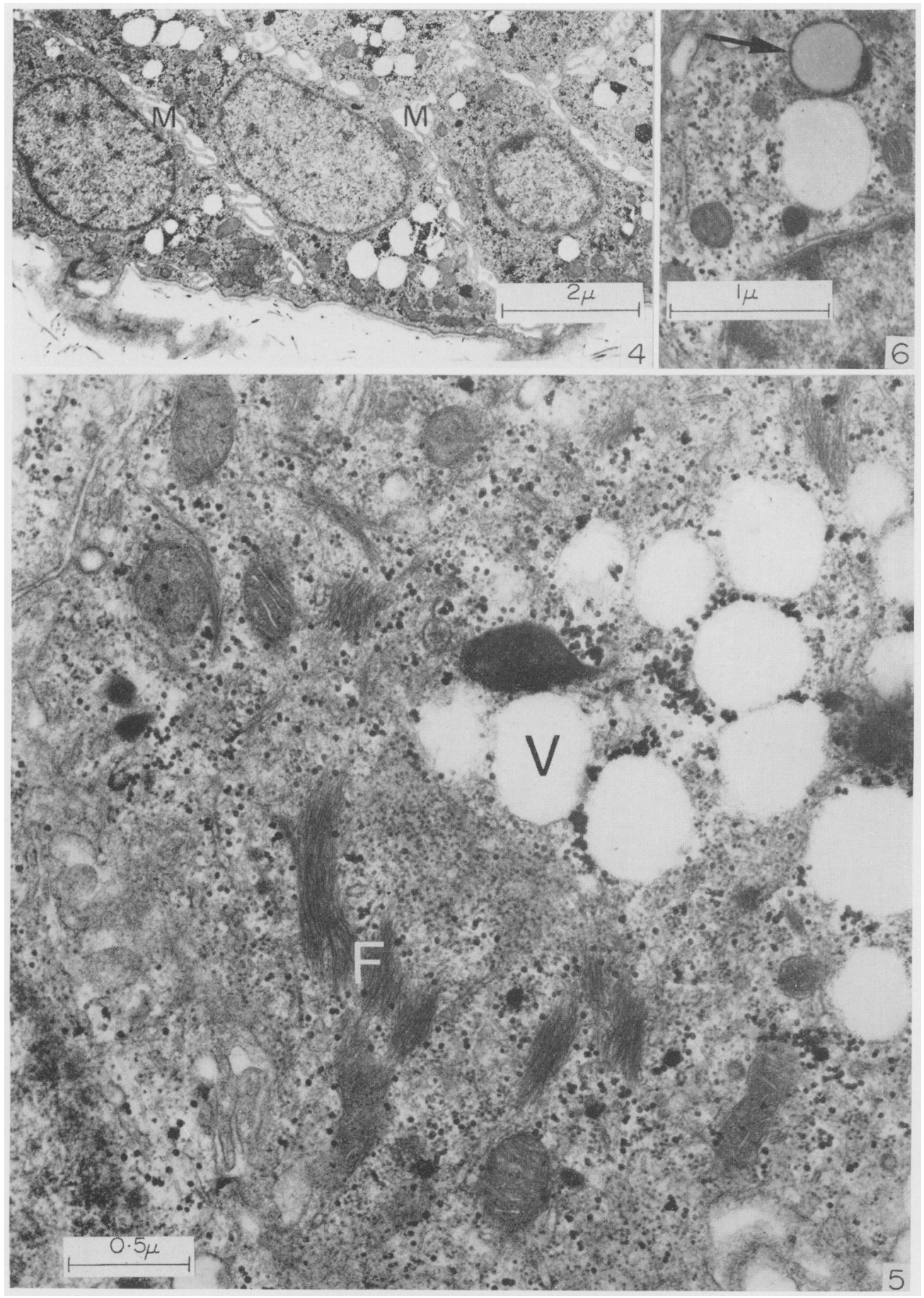




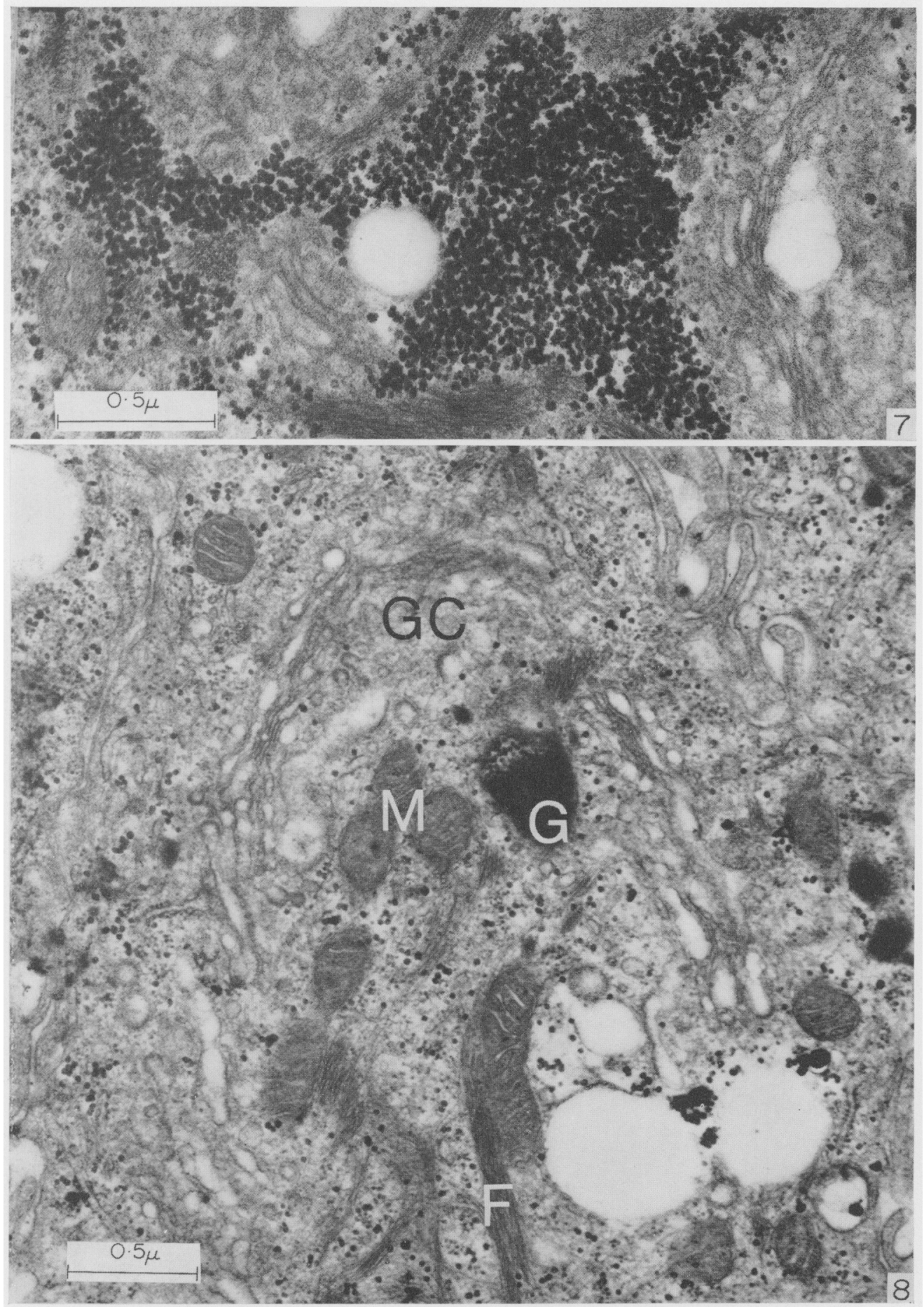


PIII:

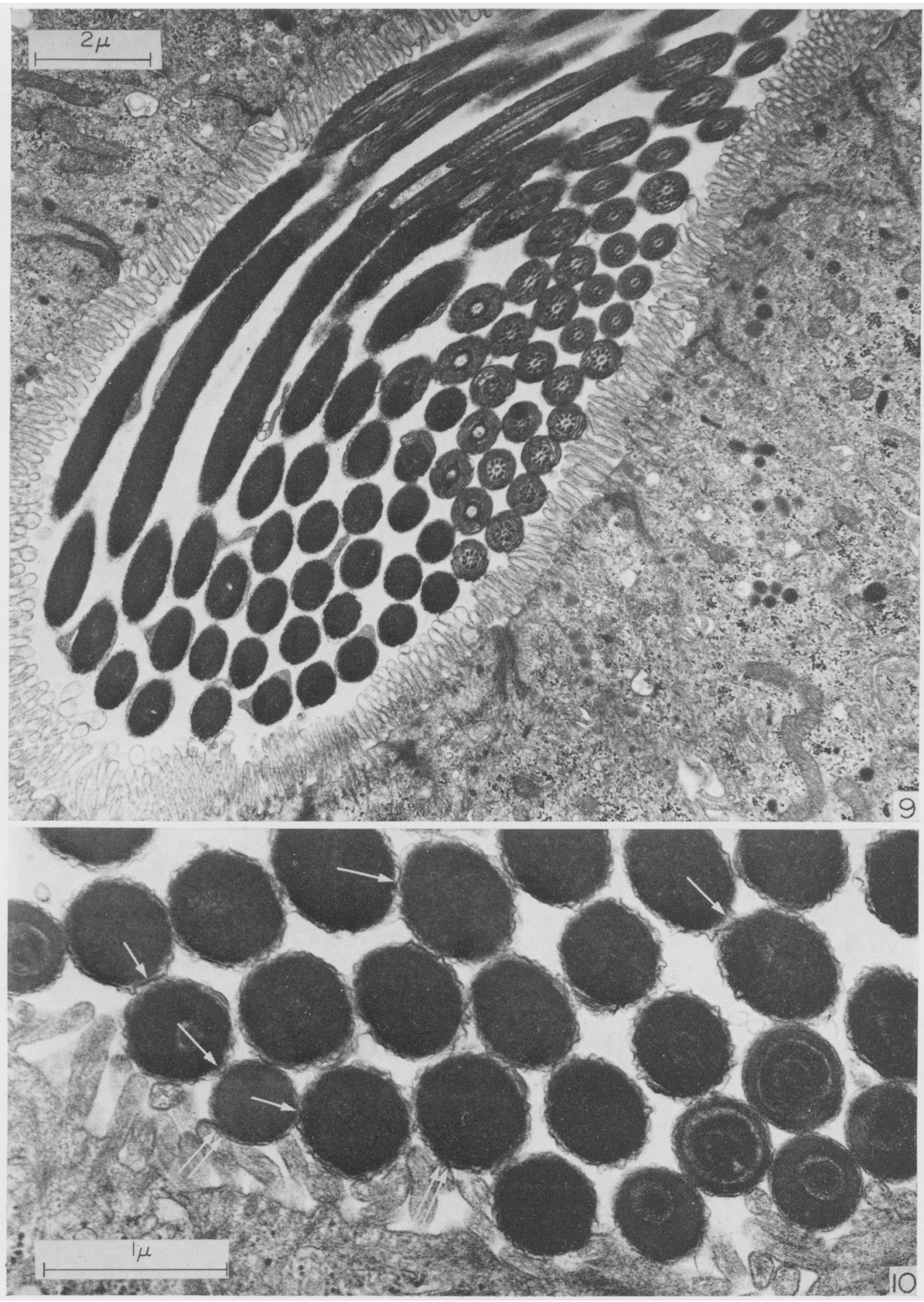


those of adjacent cells by extensive junctional complexes and more caudally by interspaced desmosomes (PI. 2, Fig. 2). The basal part of the lateral plasma membrane, however, carried numerous irregularly oriented membranous folds projecting into the intercellular space and intermeshing with those of the adjacent membrane (Pl. 3, Fig. 4). The appearance of the intercellular space here resembled that described by Ito \& Winchester (1963) for the secretory canaliculus of the parietal cell in the bat gastric mucosa. The basal plasma membrane, like the limiting basal lamina, was not folded. The subepithelial tissue was devoid of any contractile elements and.only collagenous fibres were present (Pl. 3, Fig. 4).

The spherical nucleus occupied a basal location in the cell (Pl. 3, Fig. 4) and sometimes had one or two eccentrically located nucleoli. Occasional clumping of the nuclear chromatin was observed.

The most striking feature of these cells was the presence of numerous vacuoles and dense accumulations of glycogen particles in the cytoplasm (Pl. 3, Fig. 5). The vacuoles were irregularly round and often grouped together in the apical or basal cytoplasm in a juxtanuclear location. Some of the vacuoles consisted of homogeneous dense material distributed at the periphery and electron-lucent material in the centre (Pl. 3, Fig. 6). It is likely that all the vacuoles were occupied by lipid in vivo and that it was removed during processing of the tissue. Glycogen particles occurred singly and not as rosettes (Pl. 2, Figs 2 and 3) and were therefore identified as beta particles (Fawcett, 1966). Often a massive deposition of glycogen was observed in the vicinity of the vacuoles (Pl. 3, Fig. 5; Pl. 4, Fig. 7). Excessive deposition and packing of the glycogen particles appeared sometimes to contribute to the formation of large electron-dense granules (Pl. 4, Fig. 8).

A well-developed Golgi complex was seen in the supranuclear region consisting of numerous vesicles, vacuoles and piled cisternae (PI. 4, Fig. 8) confluent with the SER. This is contrary to the observations of Burke et al. (1972), who reported an absence of these elements from non-ciliated cells. Oval or elongated mitochondria with transversely orientated cristae were scattered throughout the cytoplasm. Centrioles are found in the apical cytoplasm. Rough endoplasmic reticulum (RER) and free ribosomes were rarely seen in these cells.

Homogeneous electron-dense, membrane-bound granules were seen throughout the cytoplasm but were concentrated mainly in the apical part of the cell (Pl. 2, Figs 2 and 3). They were pleomorphic and those near the apical plasma membrane had their limiting membrane merging with it; this was interpreted as indicating secretion (Farquhar, 1969). Some of the smaller forms of the granules were seen within the Golgi cisternae. Granules showing some vacuolation were infrequently present.

Non-striated fine filaments resembling tonofibrils were usually seen in the cytoplasm either dispersed at random (PI. 2, Fig. 2) or, more commonly, packed in large bundles near the nucleus and in the apical cytoplasm (PI. 3, Fig. 5; Pl. 4, Fig. 8). Their orientation tended to follow that of the long axis of the cell. They appeared to be more abundant in the cells than was envisaged by Burke et al. (1972). 
Storage of spermatozoa

The ultrastructure of cells in the uterovaginal sperm-host gland was not affected by the presence of spermatozoa and the above accounts apply to both types of cells, regardless of whether or not the hens were inseminated. Following insemination, however, spermatozoa were found in the lumen of the gland with their number diminishing as the post-insemination period advanced.

Spermatozoa in the lumen of the gland were characteristically orientated with their long axes parallel one to another and to that of the gland; their heads pointed towards its blind distal end (PI. 5, Fig. 9). The spermatozoa showed head-to-head association ('agglutination') so that in the transverse sections of the glands, the aligned spermatozoa were usually all cut across at the same level in their structure (Pl. 5, Fig. 10). It is interesting to note that there was an intimate association between the enveloping membranes of the heads of the spermatozoa ( Pl. 5, Fig. 10). A close apposition was seen between the spermatozoa and the plasma membrane of the microvilli of the glandular epithelium; no other form of association was observed (Pl. 5, Figs 9 and 10).

\section{DISCUSSION}

The ciliated cells of the neck of the uterovaginal sperm-host glands, as noted by Burke et al. (1972), displayed the same features as the apical cells of the general epithelial lining of the uterus (Johnston, Aitken \& Wyburn, 1963) and they alone lined the proximal parts of the tubular glands. Lower down, they alternated with the non-ciliated 'glandular' cells in a region of transition and eventually they gave way to the latter in the true gland.

The non-ciliated cells of the deep regions of the host glands contained large amounts of lipid and beta-glycogen particles, a prominent Golgi complex, a number of mitochondria and secretory granules, and non-striated cytoplasmic filaments resembling tonofibrils. These features indicate an active metabolic and secretory rôle for the cells and confirm the histochemical findings of Fujii (1963) and Gilbert et al. (1968) regarding the presence of glycogen and lipid in the cells.

The nature of the secretion is not known with certainty. It cannot contain much protein since elements of RER, generally the site of protein synthesis in cells, did not abound in the non-ciliated cells. This is in accord with Gilbert et al. (1968), who suggested that there is an absence of discrete sites of protein synthesis. The Golgi complex is generally considered to be the site where simple carbohydrates are conjugated to proteins to form glycoproteins (Neutra \& Leblond, 1969). In the non-ciliated cells, however, glycogen particles were found either intimately associated with lipid droplets as subunits of electrondense granules or as part of an apocrine secretion (Pl. 2, Fig. 3; Pl. 3, Fig. 5; Pl. 4, Fig. 8). The close association of glycogen with lipid droplets, if not due to physical circumstances, is unique and hitherto has not been described in secretory cells. If it indicates a conjugation of glycogen breakdown products with lipid, it is possible that a glycolipid may be formed in the cell secretion which may be utilized by the stored spermatozoa to help sustain their fertilizing ability for prolonged periods in the host glands. If, as the observations mentioned 
above suggest, glycogen per se forms part of an apocrine secretion, it could be an additional substrate to be metabolized by spermatozoa. As yet, there are no known enzyme mechanisms in the sperm-host gland cells or spermatozoa that would lead to the utilization of glycolipids or glycogen. Glucose, if liberated, could certainly be metabolized by the spermatozoa. It has been suggested that in all species capable of prolonged sperm storage in the female reproductive tract, the 'host' tissues may play an active rôle in supporting sperm survival (Hoffman \& Wimsatt, 1972).

Earlier fine structural studies on the uterovaginal sperm-host glands (Schindler et al., 1967; Van Krey et al., 1967; Burke et al., 1972) found no evidence of contractile elements in the subepithelial stroma surrounding them, which might serve as a means to release spermatozoa. The present work confirms these observations. However, the non-ciliated cells did have a rich content of cytoplasmic filaments resembling tonofibrils either located randomly between the organelles or stacked in bundles. These filaments may contract in response to a hormonal or other chemical influence, thereby effecting contractility of the whole gland and providing a mechanism for the release of the stored spermatozoa into the lumen of the oviduct. Further studies are required to investigate this possibility. A system of intracellular contractile elements could provide a mechanism which would lead to a release of small numbers of spermatozoa over a protracted period rather than one which would cause a single forcible evacuation of all the contents of the gland. Bobr, Ogasawara \& Lorenz (1964) made observations which suggest that spermatozoa are released over a period of time in relation to ovi-position or ovulation.

Hoffman \& Wimsatt (1972) have recently studied the so-called sperm receptacles which are located on the lateral and medial walls of the posterior portion of the infundibulum of the garter snake, Thamnophis sirtalis. Motile spermatozoa were found in these receptacles for up to 3 months after mating, and as in the uterovaginal sperm-host glands of the hen, there were no contractile elements around the receptacles.

The mode of accumulation and parallel orientation of spermatozoa in the glands in the hen appears to be different from their storage in the excurrent ducts of the male (Tingari, 1971; Tingari \& Lake, 1971, 1972), where the packed spermatozoa lie in random positions. As observed by Burke et al. (1972), the heads of the spermatozoa were towards the base of the uterovaginal spermhost gland and apart from mere apposition, they did not appear to form an intimate association with the microvilli. The spermatozoa did not appear to enter the intercellular spaces as described by Fujii \& Tamura (1963). A similar orientation of spermatozoa to that seen in the hen was reported also in the sperm receptacles of the garter snake (Hoffman \& Wimsatt, 1972). In the receptacles of the latter, however, a large number of spermatozoa had their acrosomal ends apposed to or indenting the surface of the receptacle cells, suggesting a Sertoli-cell-like relationship, but there were no specialized attachments between the spermatozoa and the membrane of the receptacle cell.

The apparently intimate association established between the covering membranes of the heads such that they appear to adhere to each other in the hen is interesting. It is known that mammalian spermatozoa stick to each other 
'head-to-head' when washed with physiological salt solution in a manner similar to that of rouleaux formation by erythrocytes (Lindahl, 1968). The phenomenon has been described as agglutination, but not in the immunological sense, and is considered to be inhibited by certain factors occurring in the general secretions of the male and female tract (Lindahl, Bodin \& Brattsand, 1963; Lindahl, 1966). It remains to be seen whether antiagglutinating factors are present in secretions of the oviduct of the hen and absent in those of the uterovaginal sperm-host glands. The absence of antiagglutinating factors may account for the apparent apposition of spermatozoa with the microvilli; although this could be due to the mere pressure of large numbers of spermatozoa in the lumen.

\section{ACKNOWLEDGMENTS}

We are greatly indebted to Professor A. R. Muir for advice and useful discussions. One of us (M.D.T.) is on leave from the University of Khartoum, Sudan, and wishes to acknowledge the receipt of a Population Council Fellowship.

\section{REFERENCES}

Bobr, L. W., Lorenz, F. W. \& Ogasawara, F. X. (1962) The role of the uterovaginal junction in the storage of cock spermatozoa. Poult. Sci. 41, 1628.

Bobr, L. W., Lorenz, F. W. \& Ogasawara, F. X. (1964) Distribution of spermatozoa in the oviduct and fertility in domestic birds. I. Residence sites of spermatozoa in fowl oviducts. F. Reprod. Fert. 8,39 .

Bobr, L. W., Ogasawara, F. X. \& Lorenz, F. W. (1964) Distribution of spermatozoa in the oviduct and fertility in domestic birds. II. Transport of spermatozoa in the fowl oviduct. F. Reprod. Fert. 8, 49.

Burke, W. H., Ogasawara, F. X. \& Fugua, C. L. (1972) A study of the ultrastructure of the uterovaginal sperm-storage glands of the hen, Gallus domesticus, in relation to a mechanism for the release of spermatozoa. 7. Reprod. Fert. 29, 29.

FARQuHAR, M. G. (1969) Lysosome function in regulating secretion: disposal of secretory granules in cells of anterior pituitary gland. In: Lysosomes in Biology and Pathology, Vol. 2, p. 462. Eds. J. T. Dingle and H. B. Fell. North-Holland Publishing Co., Amsterdam and London.

FAWCETT, D. W. (1966) An atlas of fine structure: the cell. Its organelles and inclusions. Saunders, Philadelphia and London.

FujII, S. (1963) Histological and histochemical studies on the oviduct of the domestic fowl with special reference to the region of the uterovaginal juncture. Archvm histol. jap. 23, 447.

FujII, S. \& TAMura, T. (1963) Location of sperms in the oviduct of the domestic fowl with special reference to storage of sperms in the vaginal glands. F. Fac. Fish. Anim. Husb. Hiroshima Univ. 5, 145.

Giersberg, H. (1922) Untersuchungen über Physiologie und Histologie des Eileiters der Reptilien und Vögel; nebst einem Beitrag zur Fasergenese. Z. wiss. Zool. 120, 1.

Gilbert, A. B., Reynolds, M. E. \& Lorenz, F. W. (1968) Distribution of spermatozoa in the oviduct and fertility in domestic birds. V. Histochemistry of the uterovaginal sperm-host glands of the domestic hen. 7. Reprod. Fert. 16, 433.

Hoffman, L. H. \& WimsatT, W. A. (1972) Histochemical and electron microscopic observations on the sperm receptacles in the garter snake oviduct. Am. F. Anat. 134, 71 .

Ito, S. \& Winchester, R. J. (1963) The fine structure of the gastric mucosa in the bat. 7. Cell Biol. 16, 541 .

Johnston, H. S., Aitken, R. N. C. \& Wyburn, G. M. (1963) The fine structure of the uterus of the domestic fowl. 7. Anat. 97, 333.

LAKE, P. E. (1967) The maintenance of spermatozoa in the oviduct of the domestic fowl. In: Reproduction in the Female Mammal, p. 254. Proc. 13th Easter School in Agricultural Science, University of Nottingham, 1966. Eds. G. E. Lamming and E. G. Amoroso. Butterworths, London.

LiNDAHL, P. E. (1966) Sperm agglutinating and anti-agglutinating factors in normal follicular fluid from cattle. Int. F. Fert. 11, 297. 
Lindahl, P. E. (1968) Structural changes in the apical plasma membrane of the bull spermatozoon. Expl Cell Res. 53, 626.

Lindahl, P. E., Bodin, N. O. \& Brattsand, R. (1963) Sperm agglutinating and anti-agglutinating factors in normal bull seminal plasma. Int. 7. Fert. 8, 823.

Lorenz, F. W., Reynolds, M. E. \& Gilbert, A. B. (1967) Secretory activity of the sperm-host glands of the domestic fowl. Physiologist, Wash. 10, 236.

Lorenz, F. W., Reynolds, M. E. \& Howard, D. L. (1966) Endocrine control of development of sperm host glands in the chick. Fedn Proc. Fedn Am. Socs exp. Biol. 25, 190.

Maxwell, M. H. \& TREjo, F. (1970) The ultrastructure of white blood cells and thrombocytes of the domestic fowl, Br, vet. J. 126, 583.

Millonig, G. (1962) Further observations on a phosphate buffer for osmium solutions in fixation. In: Proc. 5th Int. Conf. Electron Microsc., Vol. II, p.P-8. Ed. S. S. Breese. Academic Press, New York and London.

Neutra, M. \& Leblond, G. P. (1969) The Golgi apparatus. Scient. Am. 220, 2, p. 100.

Reynolds, E. S. (1963) The use of lead citrate at high $\mathrm{pH}$ as an electron-opaque stain in electron microscopy. 7. Cell Biol. 17, 208.

Richardson, K.C. (1935) The secretory phenomena in the oviduct of the fowl including the process of shell formation examined by the microincineration technique. Phil. Trans. R. Soc. B, 225, 149.

Schindler, H., Ben-David, E., Hurwitz, S. \& Kempenich, O. (1967) The relation of spermatozoa to the glandular tissue in the storage sites of the hen oviduct. Poult. Sci. 46, 1462.

Stempak, J. G. \& Ward, R. T. (1964) An improved staining method for electron microscopy. F. Cell Biol. 22, 697.

TAKedA, A. (1967) Behaviour of spermatozoa in the genital tract of the hen. IV. Persistence of spermatozoa and their transport in the hen's oviduct following artificial insemination. Jap. Poult. Sci. 4,62 .

TINGARI, M.D. (1971) On the structure of the epididymal region and ductus deferens of the domestic fowl (Gallus domesticus). 7. Anat. 109, 423.

Tingari, M.D. \& LAKE, P.E. (1971) Uptake of spermatozoa by the ductuli efferentes after ligation of the ductus deferens of the domestic fowl. F. Anat. 109, 353.

Tingari, M.D. \& LAKE, P.E. (1972) Ultrastructural evidence for resorption of spermatozoa and testicular fluid in the excurrent ducts of the testis of the domestic fowl, Gallus domesticus. 7 . Reprod. Fert. 31, 373.

Van Krey, H. P., Ogasawara, F. X. \& Pangborn, J. (1967) Light and electron microscopic studies of possible sperm gland emptying mechanisms. Poult. Sci. 46, 69. 